Taxonomy and systematics

\title{
Macroparasites of silversides (Atherinopsidae: Odontesthes) in Argentina
}

\author{
Macroparásitos de pejerreyes (Atherinopsidae: Odontesthes) en Argentina \\ Verónica Flores $^{\text {a, } *}$, Liliana Semenas ${ }^{a}$, Carlos Rauque ${ }^{a}$, Rocío Vega ${ }^{a}$, \\ Valeria Fernandez ${ }^{a}$, María Lattuca ${ }^{b}$ \\ ${ }^{a}$ Laboratorio de Parasitología, Instituto de Investigaciones en Biodiversidad y Medioambiente del Consejo Nacional de Investigaciones Científicas y Técnicas - \\ Universidad Nacional del Comahue, Quintral 1250, 8400 Bariloche, Río Negro, Argentina \\ ${ }^{\mathrm{b}}$ Laboratorio de Ecofisiología, Centro Austral de Investigaciones Científicas (CADIC-CONICET), Bernardo Houssay 200, V9410BFD Ushuaia, Tierra del Fuego, \\ Argentina
}

Received 26 September 2014; accepted 7 March 2016

Available online 17 August 2016

\begin{abstract}
This study presents new geographical distribution records for the macroparasites of the marine Odontesthes nigricans (Richardson, 1848 ) (89 wild specimens), and for the freshwater silversides Odontesthes bonariensis (Valenciennes, 1835) (43 wild and 108 cultured specimens), and Odontesthes hatcheri (Eigenmann, 1909) (183 wild specimens) from Argentina. These data represent records of 12 parasite taxa for O. nigricans, 8 for $O$. bonariensis, and 19 for $O$. hatcheri, which include digeneans, monogeneans, cestodes, nematodes, acantocephalans, mollusks, copepods, and branchiurans. For cultured $O$. bonariensis, the records of the present study correspond to the first reports of parasites in the literature. This work provides also data on site of infection, parasite load, and development stages for the parasite species.

All Rights Reserved (C) 2016 Universidad Nacional Autónoma de México, Instituto de Biología. This is an open access item distributed under the Creative Commons CC License BY-NC-ND 4.0.

Keywords: Odontesthes nigricans; Odontesthes bonariensis; Odontesthes hatcheri; Parasites; Argentina; Freshwater; Marine; Wild; Cultured

\section{Resumen}

Este estudio presenta nuevos registros de distribución geográfica de macroparásitos del pejerrey marino Odontesthes nigricans (Richardson, 1848) (89 especímenes silvestres), de los pejerreyes de agua dulce Odontesthes bonariensis (Valenciennes, 1835) (43 ejemplares silvestres y 108 cultivados) y de Odontesthes hatcheri (Eigenmann, 1909) (183 especímenes silvestres) en Argentina. Doce taxones parásitos se registraron para $O$. nigricans, 8 para $O$. bonariensis y 19 para $O$. hatcheri, incluyendo digéneos, monogéneos, cestodos, nematodos, acantocéfalos, moluscos, copépodos y branquiuros. Para los ejemplares de $O$. bonariensis de cultivo, los registros del presente estudio corresponden a los primeros sobre parásitos en la literatura. Además, se presentan datos sobre la localización del parásito, sus valores de infección y sus estados de desarrollo.

Derechos Reservados ( 2016 Universidad Nacional Autónoma de México, Instituto de Biología. Este es un artículo de acceso abierto distribuido bajo los términos de la Licencia Creative Commons CC BY-NC-ND 4.0.
\end{abstract}

Palabras clave: Odontesthes nigricans; Odontesthes bonariensis; Odontesthes hatcheri; Parásitos; Argentina; Agua dulce; Marinos; Silvestres; De cultivo

\section{Introduction}

The species of Odontesthes (silversides) compose the most representative genus of Atherinopsidae, containing 19 species

\footnotetext{
* Corresponding author.

E-mail address: veronica.flores@ crub.uncoma.edu.ar (V. Flores).

Peer Review under the responsibility of Universidad Nacional Autónoma de México.
}

(Dyer, 2006). The silversides have great adaptability to different habitats and are distributed in marine, brackish, and freshwater environments (Dyer, 2006). Due to the flavor of the meat, these fishes are important in recreational fishery, commercial exploitation, and aquaculture (Grosman, 2001). Odontesthes bonariensis (Valenciennes, 1835) is the only cultured species, and has been widely used for repopulation purposes and have been introduced into Europe, Asia, and Africa (Tombari \& Volpedo, 2008). 
In Argentina, studies on freshwater silversides are mainly focused on culture, genetics, physiology, and ecology of O. bonariensis (Colautti, Garcia, Balboni, \& Baigún, 2010; Grosman, 2001), and of Odontesthes hatcheri (Eigenmann, 1909) (Ruiz, 2007). The information on the marine silversides is limited, based mainly on Odontesthes nigricans (Richardson, 1848 ) and focused on the physiology of the specimens (Lattuca et al., 2009).

Although silversides species are widely distributed, reports of parasites from wild fishes are scarce and scattered (Carballo, 2008; Carballo, Laurenti, \& Cremonte, 2011; Carballo, Navone, \& Cremonte, 2011; Carballo, Cremonte, Navone, \& Timi, 2012; Drago, 2012; Mancini, Rodríguez, Prosperi, Salinas, \& Bucco, 2006; Mancini et al., 2008; Ortubay, Semenas, Úbeda, Quaggiotto, \& Viozzi, 1994). Besides publications on rearing silversides, there is no published information on their parasites (Tanzola, Semenas, \& Viozzi, 2009). The objective of the present work is to report the macroparasite fauna of the wild marine $O$. nigricans and the wild freshwater $O$. bonariensis and $O$. hatcheri, and the cultured $O$. bonariensis.

\section{Materials and methods}

A total of $89 O$. nigricans were collected from 2 marine sites, $151 O$. bonariensis were collected from 5 sites, and $183 \mathrm{O}$. hatcheri were collected from 13 sites, both the latter from freshwater environments (Fig. 1; Table 1). The fish were captured using gill and seine nets. Cultured $O$. bonariensis were collected from outdoor man-made ponds and indoor fiberglass tanks located within the campus of INTECH (Instituto Tecnológico de Chascomús), which were supplied with underground waters, and from floating cages located in Lacombe and Chascomús Pampean Lakes (Fig. 1; Table 1). Specimens of $O$. hatcheri and $O$. bonariensis were transported fresh to the laboratory, and those of $O$. nigricans were slit opened and fixed in 5\% formalin in the field. Fish were measured, and necropsied to examine fins, skin, eyes, gills, and all internal organs with the aid of a dissecting microscope. The parasites were collected, identified, and counted. Prevalence and mean intensity were calculated. New geographical record refers to the first date that a parasite is reported in a new biogeographic region, ecoregion or basin, and new host record refers to the first time that a parasite is cited for a new host species. Furthermore, we followed the classification proposed by Niewiadomska (2002) for the family Diplostomidae, who considered as valid the genera Diplostomum, Austrodiplostomum, Tylodelphys, and Dolichorchis. Measurements of specimens are given in $\mu \mathrm{m}$. Voucher specimens of parasites were deposited in the Colección Helmintológica del Museo de La Plata, Argentina.

\section{Results}

The data obtained represent 15 new geographical records and 2 new host records for $O$. nigricans (Fig. 2; Table 2); 2 new geographical records, 1 new host record (T. cardiophilus), and a new species (Gyrodactylus sp.) for $O$. bonariensis (Fig. 3;

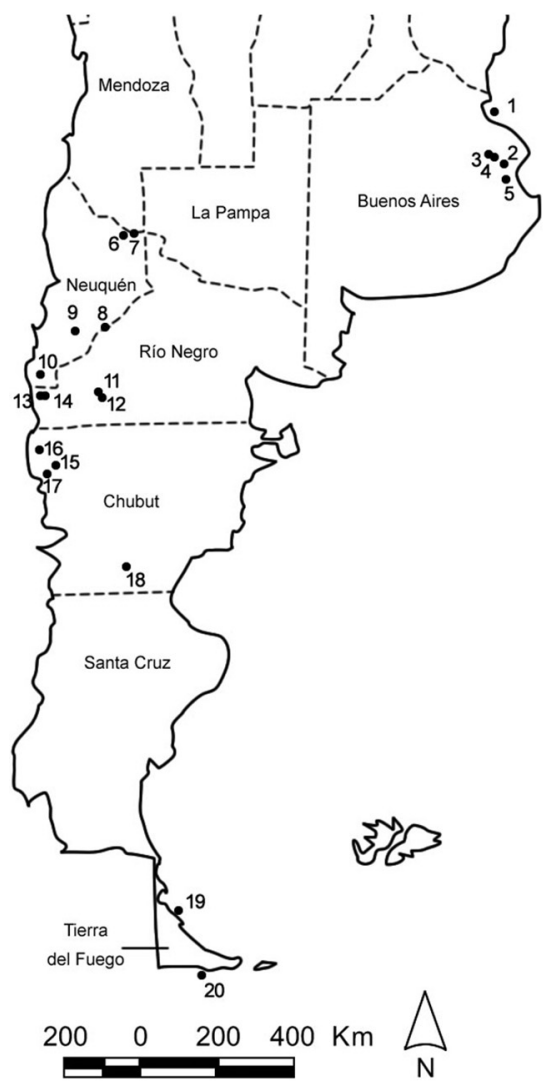

\author{
Odontesthes bonariensis \\ 1. Wild fish from La Plata River ( $34^{\circ} 28^{\prime} \mathrm{S} 58^{\circ} 23^{\prime} \mathrm{W}$ ) \\ 2. Man-made Pond (INTECH) ( $35^{\circ} 37^{\prime} \mathrm{S} 57^{\circ} 59^{\prime} \mathrm{W}$ ) \\ 3. Cages from Chascomús Pampean Lake ( $35^{\circ} 37^{\prime} \mathrm{S} 58^{\circ} 00^{\prime} \mathrm{W}$ ) \\ 4. Wild fish Chascomús Pampean Lake ( $\left.35^{\circ} 37^{\prime} \mathrm{S} 58^{\circ} 00^{\prime} \mathrm{W}\right)$

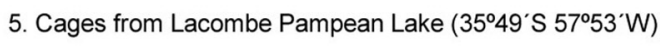 \\ Odontesthes hatcheri \\ 6. Marimenuco Reservoir $\left(38^{\circ} 32^{\prime} \mathrm{S} 69^{\circ} 25^{\prime} \mathrm{W}\right)$ \\ 7. Neuquén River ( $38^{\circ} 34^{\prime} \mathrm{S} 68^{\circ} 23^{\prime} \mathrm{W}$ ) \\ 8. Piedra del Águila Reservoir $\left(40^{\circ} 02^{\prime} \mathrm{S} 70^{\circ} 04^{\prime} \mathrm{W}\right)$ \\ 9. Caleufu River $\left(40^{\circ} 23^{\prime} \mathrm{S} 70^{\circ} 44^{\prime} \mathrm{W}\right)$ \\ 10. Pond in Villa la Angostura $\left(40^{\circ} 50^{\prime} \mathrm{S} 71^{\circ} 38^{\prime} \mathrm{W}\right)$ \\ 11. Carrilafquen Lake $\left(41^{\circ} 07^{\prime} \mathrm{S} 69^{\circ} 25^{\prime} \mathrm{W}\right)$ \\ 12. Carrilafquen Chica Lake $\left(41^{\circ} 12^{\prime} \mathrm{S} 69^{\circ} 25^{\prime} \mathrm{W}\right)$ \\ 13. Morenito Lake $\left(41^{\circ} 02^{\prime} \mathrm{S} 68^{\circ} 34^{\prime} \mathrm{W}\right)$ \\ 14. Moreno Oeste Lake $\left(41^{\circ} 06^{\prime} \mathrm{S} 71^{\circ} 32^{\prime} \mathrm{W}\right)$ \\ 15. Lezana Lake $\left(42^{\circ} 27^{\prime} \mathrm{S} 71^{\circ} 29^{\prime} \mathrm{W}\right)$ \\ 16. Epuyen Lake $\left(42^{\circ} 15^{\prime} \mathrm{S} 71^{\circ} 25^{\prime} \mathrm{W}\right)$ \\ 17. Rivadavia Lake $\left(42^{\circ} 36^{\prime} \mathrm{S} 71^{\circ} 39^{\prime} \mathrm{W}\right)$ \\ 18. Musters Lake $\left(45^{\circ} 25^{\prime} \mathrm{S} 69^{\circ} 11^{\prime} \mathrm{W}\right)$ \\ Odontesthes nigricans \\ 19. Punta Maria (Atlantic Ocean) $\left(53^{\circ} 57^{\circ} \mathrm{S} 67^{\circ} 27^{\prime} \mathrm{W}\right)$ \\ 20. Varela Bay (Atlantic Ocean) $\left(54^{\circ} 52^{\prime} \mathrm{S} 67^{\circ} 16^{\prime} \mathrm{W}\right)$
}

Figure 1. Location of the sampling sites of the silversides and their geographical coordinates in Argentina. 
Table 1

Data of silversides, localities of collections, sample, date and size; $\S$ cultured fish.

\begin{tabular}{|c|c|c|c|c|c|}
\hline \multirow[t]{2}{*}{ Host } & \multirow[t]{2}{*}{ Localities } & \multirow[t]{2}{*}{ Sample date } & \multirow[t]{2}{*}{ Sample size } & \multicolumn{2}{|c|}{ Standard fish size $(\mathrm{cm})$} \\
\hline & & & & Mean & Range \\
\hline \multirow[t]{4}{*}{ O. nigricans } & Punta María & Nov. 2010 & 67 & 16.8 & $9-25$ \\
\hline & Varela Bay & Sep. 2010 & & & \\
\hline & & Jan. 2011 & 22 & 22.1 & $18-25$ \\
\hline & & Mar. 2011 & & & \\
\hline \multirow[t]{11}{*}{ O. bonariensis } & La Plata River & Sep. 2011 & 11 & 18.5 & $10-27$ \\
\hline & Man-made Pond (INTECH) ${ }^{\S}$ & Nov. 2007 & 10 & 11.4 & $9-16$ \\
\hline & Chascomús Pampean Lake ${ }^{\S}$ & Mar. 2008 & 77 & 10.3 & $8-14$ \\
\hline & Chascomús Pampean Lake & Mar. 2008 & 32 & 14.6 & $9-24$ \\
\hline & Lacombe Pampean Lake ${ }^{\S}$ & Nov. 2007 & 21 & 14 & $13-15$ \\
\hline & Marimenuco Reservoir & Mar. 2001 & 7 & 14.0 & $3-31$ \\
\hline & Neuquén River & Oct. 2011 & 5 & 26.7 & $24-30$ \\
\hline & Piedra del Águila Reservoir & Feb.1999 & 1 & 38.0 & 38 \\
\hline & Caleufu River & Mar. 2006 & 3 & 7.0 & $6-8$ \\
\hline & Pond in Villa la Angostura & Jan. 2007 & 2 & 2.7 & $2-3$ \\
\hline & Carrilafquen Lake & Oct. 2005 & 10 & 21.1 & $20-22$ \\
\hline \multirow[t]{11}{*}{ O. hatcheri } & Carrilafquen Chica Lake & Oct. 2004 & 58 & 14.6 & $8-30$ \\
\hline & & Aug. 2005 & & & \\
\hline & Morenito Lake & Feb. 1999 & 10 & 25.4 & $17-31$ \\
\hline & & Nov. 2000 & & & \\
\hline & Moreno Oeste Lake & Mar.1999 & 16 & 31.1 & $28-36$ \\
\hline & & Aug. 2000 & & & \\
\hline & Lezana Lake & Dec. 2010 & 31 & 6.9 & $6-9$ \\
\hline & & Jan.2011 & & & \\
\hline & Epuyen Lake & Mar.2003 & 3 & 25.3 & $22-27$ \\
\hline & Rivadavia Lake & Feb. 2011 & 27 & 12.8 & $6-18$ \\
\hline & Musters Lake & Oct. 2012 & 10 & 29.8 & $27-32$ \\
\hline
\end{tabular}

Table 3); and 24 new geographical records and 1 new host record (Steganoderma szidati) for O. hatcheri (Fig. 4; Table 4). Prevalence and mean intensity for each parasite species, which include digeneans, monogeneans, cestodes, nematodes, acantocephalans, mollusks, copepods and branchiurans, are given in Tables 2-4.

The marine silverside, $O$. nigricans, was parasitized by the digeneans Diplostomum sp., Lecithaster sp., Proctotrema bartolii Carballo, Laurenti, \& Cremonte, 2011. The following nematodes Acuariinae gen. et sp., Cosmocephalus sp., Contracaecum sp., Hysterothylacium sp. and Cucullanus sp., the acanthocephalans Hypoechinorhynchus sp. and Corynosoma sp., and the copepods Caligus rogercresseyi (Boxshall \& Bravo, 2000) and Peniculus sp. were also recorded (Table 2). The specimens of Diplostomum were assigned to this genus since they are metacercariae of the "Diplostomulum" type (not encysted metacercariae), which were localized in the lens of fish. The metacercariae measured 260-701 in length $\times 144-326$ width, had the anterior end of the body trilobate, with small lateral protuberances (lappets) on either side of the oral sucker (36-72 long $\times$ 36-65 wide); the ventral sucker $(26-72$ long $\times 29-65$ wide) was located postequatorially and is similar in size to that of the oral sucker. Just behind the ventral sucker there is a longitudinal holdfast organ (65-168 long). The specimens of Lecithaster sp. collected presented a 4-lobed ovary and a vitellarium rosette-shaped with 7 lobes. The larvae 3 of Acuariinae gen. et sp. have well developed pseudolabia, but the lateral alae are absent, therefore they could not be assigned to any known genus. The Cucullanus specimens collected in this study (1 male and 2 immature females) have the deirids located in the first third of the esophagus (182-193 from the anterior end), absence of papillae anterior to ventral sucker, presence of gubernaculum, and spicules reaching anterior end of ventral sucker. Peniculus sp. have a cephalothorax of 454 long $\times 511$ wide; a neck of 227-284 long, a trunk 3,550-4,658 long $\times 880-1,227$ wide, a ratio length to wide trunk of 3.6-4.0, with 4 swimming legs, with 3 and 4 further apart from legs 1 and 2 .

The freshwater silverside $O$. bonariensis was parasitized by metacercariae of Austrodiplostomum mordax Szidat and Nani, 1951, Tylodelphys cardiophilus Szidat, 1969, Ascocotyle sp., and Phagicola sp., the monogenean Gyrodactylus sp., the cestode Cangatiella macdonaghi (Szidat \& Nani, 1951), the nematode Contracaecum sp., and the branchiuran Argulus sp. (Table 3). Odontesthes hatcheri was parasitized by the digeneans A. mordax, Diplostomum sp., Tylodelphys barilochensis Quaggiotto and Valverde, 1992, T. cardiophilus, Tylodelphys destructor Szidat and Nani, 1951, Ascocotyle sp., Phagicola sp., Stephanoprora uruguayense Holcman-Spector and Olagüe, 1989, Steganoderma macrophallus Szidat and Nani, 1951, and Steganoderma szidati Viozzi, Flores and Ostrowski de Núñez, 2000, the cestodes C. macdonaghi, the nematodes Contracaecum sp., Hysterothylacium patagonense Moravec, Urawa and Coria, 1997, and Camallanus corderoi Torres, Teuber and Miranda, 1990, the acanthocephalans Acanthocephalus tumescens (von Linstow, 1896) and Pomphorhynchus patagonicus Ortubay, Úbeda, Semenas and Kennedy, 1991, the mollusk 


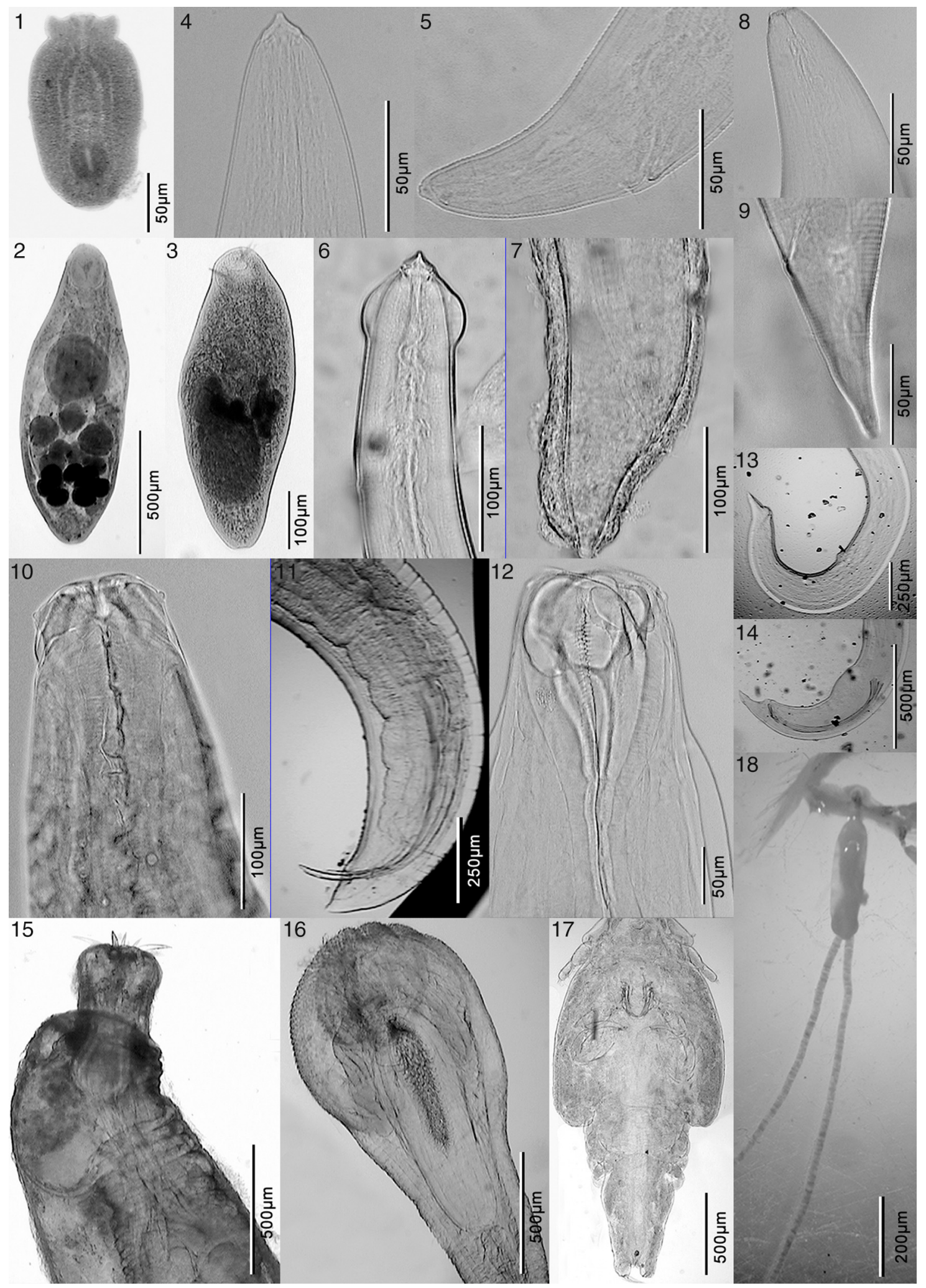

Figure 2. Microphotographs of Odontesthes nigricans parasites. 1, Diplostomum sp.; 2, Lecithaster sp.; 3, Proctotrema bartolii; 4, anterior end of Acuariinae sp.; 5, posterior end of Acuariinae sp.; 6, anterior end of Cosmocephalus sp.; 7, posterior end of Cosmocephalus sp.; 8, anterior end of Contracaecum sp.; 9, posterior end of Contracaecum sp.; 10, anterior end of Hysterothylacium sp.; 11, posterior end of Hysterothylacium sp.; 12, anterior end of Cucullanus sp.; 13, posterior end of a Cucullanus sp. female; 14, posterior end of a Cucullanus sp. male; 15, forebody of Hypoechinorhynchus sp.; 16, Corynosoma sp.; 17, Caligus sp.; 18, Peniculus sp. 
Table 2

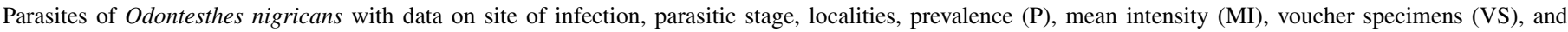
collection number $(\mathrm{CN})$. A, adult; C, Cysthacanth; L3, Larva 3; M, Metacercaria. *New geographical record; ${ }^{\ddagger}$ new host record; ${ }^{\S}$ cultured fish.

\begin{tabular}{|c|c|c|c|c|c|c|}
\hline Parasite & Site & Stage & Locality & $P(\%)$ & MI & VS-CN \\
\hline Diplostomum sp. ${ }^{¥}$ & Lens & M & Varela* & 8.6 & 8.0 & MLP-He 7125 \\
\hline Lecithaster sp. & Intestine & A & Varela* & 30.0 & 11.6 & MLP-He 7126 \\
\hline Proctotrema bartolii & Intestine & A & Punta María* & 48.4 & 16.5 & MLP-He 7127 \\
\hline \multirow[t]{2}{*}{ Acuariinae gen. et sp..$^{¥}$} & \multirow[t]{2}{*}{ Liver and abdominal cavity } & \multirow[t]{2}{*}{ L3 } & Punta María* & 12.9 & 1.8 & \multirow[t]{2}{*}{ MLP-He 7128} \\
\hline & & & Varela & 15.7 & 1.9 & \\
\hline \multirow[t]{2}{*}{ Cosmocephalus sp. } & \multirow[t]{2}{*}{ Liver and abdominal cavity } & \multirow[t]{2}{*}{ L3 } & Punta María* & 9.7 & 4.0 & \multirow[t]{2}{*}{ MLP-He 7129} \\
\hline & & & Varela* & 8.6 & 1.6 & \\
\hline Contracaecum sp. & Abdominal cavity & L3 & Varela* & 1.4 & 1.0 & \\
\hline Hysterothylacium sp. & Intestine & L3 & Punta María & 3.2 & 1.0 & MLP-He 7130 \\
\hline Cucullanus sp. & Intestine & A & Varela* & 2.9 & 1.0 & \\
\hline \multirow[t]{2}{*}{ Hypoechinorhynchus sp. } & \multirow[t]{2}{*}{ Intestine } & \multirow[t]{2}{*}{ A } & Varela* & 2.9 & 1.5 & \multirow[t]{2}{*}{ MLP-He 7131} \\
\hline & & & Punta María* & 9.7 & 4.0 & \\
\hline \multirow[t]{2}{*}{ Corynosoma sp. } & \multirow[t]{2}{*}{ Mesenteries, liver } & \multirow[t]{2}{*}{$\mathrm{C}$} & Varela* & 7.1 & 1.0 & \multirow[t]{2}{*}{ MLP-He 7132} \\
\hline & & & Punta María* & 35.5 & 3.4 & \\
\hline \multirow[t]{2}{*}{ Caligus rogercresseyi } & \multirow[t]{2}{*}{ Dorsal, caudal fins } & \multirow[t]{2}{*}{ A } & Varela* & 11.4 & 1.8 & \multirow[t]{2}{*}{ MLP-Cr 27001} \\
\hline & & & Punta María* & 29.0 & 1.0 & \\
\hline Peniculus sp. & Body surface, fins & A & Varela* & 28.6 & 5.3 & MLP-Cr 27002 \\
\hline
\end{tabular}

Diplodon chilensis Gray, 1828 and the copepod Ergasilus sieboldi von Nordman, 1832 (Table 4). As mentioned above, the metacercariae collected from the lens of $O$. hatcheri, which were the diplostomulum type were assigned to the genus Diplostomum. They measured 509-701 in length $\times 259-336$ width. They also had the anterior end of the body trilobate, with small lateral lappets on either side of the oral sucker (53-82 long $\times 48-72$ wide); the ventral sucker (36-60 long $\times 43-60$ wide) is oval to round, located postequatorially and similar in size to that of the oral sucker. Just posterior to ventral sucker is the holdfast organ (96-144 long).

For cultured $O$. bonariensis, the parasite richness was 1 parasite species (Gyrodactylus sp.) taken from samples from indoor fiberglass tanks, and for those cultured outdoor in man-made ponds, 5 species (A. mordax, T. cardiophilus, C. macdonaghi, Contracaecum sp., and Argulus sp.) for fish reared in cages of Lacombe Pampean Lake, and also 5 species (Ascocotyle sp., Phagicola sp., Gyrodactylus sp., C. macdonaghi, and Contracaecum sp.) for those collected from cages of Chascomús Pampean Lake (Table 3).

\section{Discussion}

Specimens belonging to Digenea, Monogenea, Cestoda, Nematoda, Acanthocephala, Mollusca, Copepoda, and Branchiura are reported herein. Since larvae were the most common stages found in previous as well as, in the present work, the taxonomic identification at species level is difficult, considering that many of these parasites and their life cycles are not yet elucidated. All records reported in this study represent 41 new geographical records, 4 new host records and 1 new parasite species.

For O. nigricans, the parasites Diplostomum sp. and Acuariinae gen. et sp. were reported for the first time, and Cucullanus sp. may be a new parasite species. With regard to the Diplostomum metacercaria, we assumed that the metacercariae of $O$. nigricans and $O$. hatcheri belong to the same species as they show similar morphometric characteristics. Diplostomum species that have been found in the Antarctic region are $D$. minutum Szidat, 1964; D. antarcticum Freiler, 1986; and D. dominicanum Freiler, 1986 recorded from the kelp gull Larus
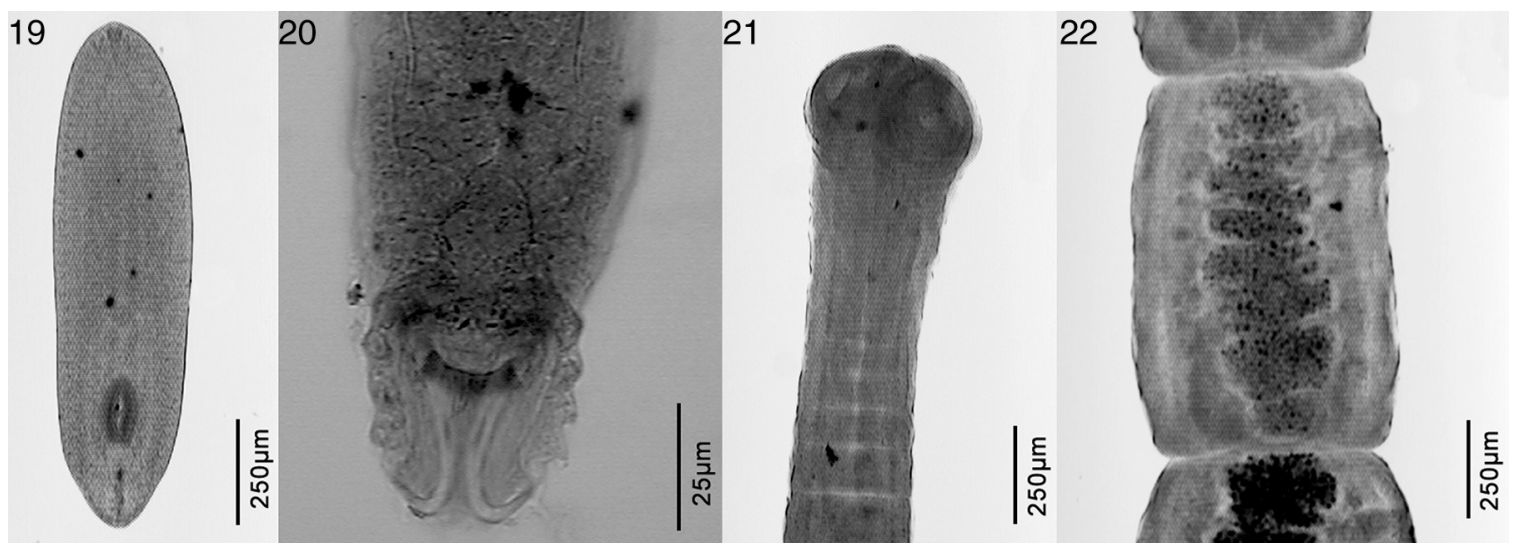

Figure 3. Microphotographs of Odontesthes bonariensis parasites. 19, Tylodelphys cardiophilus; 20, Gyrodactylus sp.; 21, escolex of Cangatiella macdonaghi; 22, proglotids of Cangatiella macdonaghi. 
Table 3

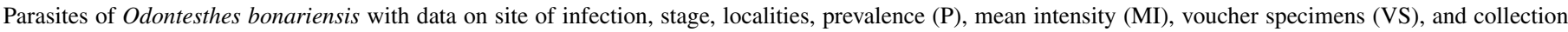
number $(\mathrm{CN}) ;{ }^{\S}$ cultured fish; A, adult; L3, Larva 3; M, Metacercaria. $*$ New geographical record; ${ }^{\ddagger}$ new host record.

\begin{tabular}{|c|c|c|c|c|c|c|}
\hline Parasite & Site & Stage & Locality & $P(\%)$ & MI & VS-CN \\
\hline Austrodiplostomum mordax & brain & M & Lacombe $^{\S}$ & 100 & 13.8 & \\
\hline Tylodelphys cardiophilus ${ }^{¥}$ & pericardic cavity & M & Lacombe $^{\S *}$ & 28.5 & 1.3 & MLP-He 7133 \\
\hline \multirow[t]{2}{*}{ Ascocotyle sp. } & heart & M & Chascomús $^{\S}$ & 42.9 & 3.3 & \\
\hline & & & Chascomús & 31.3 & 10.6 & \\
\hline Phagicola sp. & gills & M & Chascomús ${ }^{\S}$ & 5.2 & 2.0 & \\
\hline \multirow[t]{4}{*}{ Gyrodactylus sp. } & gills and fins & A & fiberglass tanks & 28.6 & 6.7 & MLP-He 7134 \\
\hline & & & man made pond & 60.0 & 3.4 & \\
\hline & & & Chascomús $^{\S}$ & 90.5 & 4.5 & \\
\hline & & & Chascomús & 31.3 & 10.6 & \\
\hline \multirow[t]{3}{*}{ Cangatiella macdonaghi } & intestine & A & Lacombe $^{\S}$ & 85.7 & 13.8 & \\
\hline & & & Chascomús ${ }^{\S}$ & 10.4 & 9.1 & MLP-He 7135 \\
\hline & & & Chascomús & 96.9 & 66.7 & \\
\hline \multirow[t]{4}{*}{ Contracaecum sp. } & abdominal cavity & L3 & La Plata River & 9.1 & 1.0 & \\
\hline & & & Lacombe $^{\S}$ & 14.3 & 1.7 & \\
\hline & & & Chascomús ${ }^{\S}$ & 3.9 & 1.0 & \\
\hline & & & Chascomús & 25.0 & 1.6 & \\
\hline Argulus sp. & tegument & A & Lacombe $^{\S *}$ & 4.7 & 1.0 & \\
\hline
\end{tabular}

dominicanus (González-Acuña et al., 2009). The metacercariae of Diplostomum found in $O$. nigricans and $O$. hatcheri could possibly correspond to $D$. minutum since adults of this species have been reported in L. dominicanus in Chubut and in Antarctica (Niewiadomska, Zdzitowiecki, \& Ostrowski-de Núñez, 1989), near the site of the present study. It has been pointed out that lens metacercariae of Diplostomum have a low specificity (Locke et al., 2015), so the marine silverside could be infected with cercariae of Diplostomum when they ascend the rivers in the Magellan Strait (Dyer, 2000).

Lecithaster australis Prudhoe and Bray, 1973 and L. micropsi Zdzitowiecki, 1992 were recorded in several species of nothotenids and gadiids in the South West Atlantic Ocean (Suriano \& Sutton, 1981; Zdzitowiecki, 1992). The specimens of Lecithaster collected in the present study could not be assigned to any of those species, due to morphometric differences with the known species. The specimens are similar to those collected from $O$. nigricans and $O$. smitti in Nuevo and San José Gulfs, Chubut Province (Argentina), but the identification has not been determined (Carballo, 2008). The larva 3 of
Cosmocephalus sp. most likely belongs to Cosmocephalus obvelatus (Creplin, 1825), since this species was recovered in the Chubut Province from $O$. nigricans parasitizing the same infection site (Carballo, Navone, et al., 2011). Four Cucullanus species have been described in the Argentinean Sea. Cucullanus marplatensis Daniel, Timi, and Sardella, 2002 was reported for Odontesthes species (Carballo, Laurenti, et al., 2011; Daniel et al., 2002). The Cucullanus specimens collected in this study differ from all the species of Cucullanus reported in Argentinean Sea. This finding would constitute a new parasite species. Peniculus fistula von Nordmann, 1832 was first recorded in the Strait of Magellan in an unknown host (Stuardo \& Fagetti, 1961). Later, Peniculus sp. was registered in O. nigricans and O. smitti in the North Patagonian Gulfs (Carballo, Navone, et al., 2011). The specimens recovered in this work from $O$. nigricans, have a smaller length to width ratio (3.6-4.0) than $P$. fistula, which shows a trunk more than 6 times longer than wide (Alexander, 1983). They are similar to $P$. ostraciontis Yamaguti, 1939 and $P$. truncates Shiino, 1956 considering the distribution of swimming legs; however, our specimens cannot be assigned to any of these

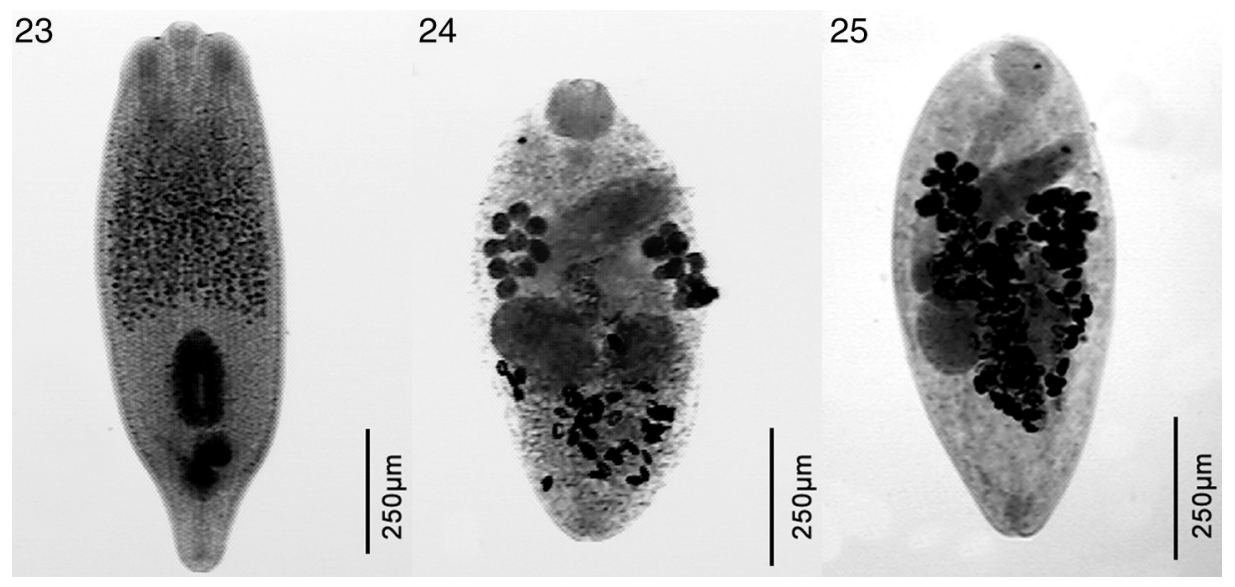

Figure 4. Microphotographs of Odontesthes hatcheri parasites. 23, Austrodiplostomum mordax; 24, Steganoderma macrophallus; 25, Steganoderma szidati. 
Table 4

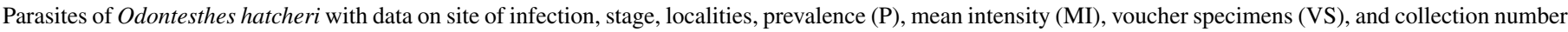
(CN); A, adult; G, Glochidium; L3, Larva 3; M, Metacercaria. *New geographical record; ${ }^{¥}$ new host record.

\begin{tabular}{|c|c|c|c|c|c|c|}
\hline Parasite & Site & Stage & Locality & $P(\%)$ & MI & VS-CN \\
\hline Austrodiplostomum mordax & Brain & M & $\begin{array}{l}\text { Carrilafquen Chica } \\
\text { El Chañar } \\
\text { Marimenuco }\end{array}$ & $\begin{array}{l}50 \\
60 \\
14.3\end{array}$ & $\begin{array}{r}6.3 \\
5.0 \\
41.0\end{array}$ & MLP-He 7136 \\
\hline Diplostomum sp. & Eyes & M & Musters & 80 & 80.5 & \\
\hline Tylodelphys barilochensis & Brain & M & Moreno & 5.9 & 1.0 & \\
\hline Tylodelphys cardiophilus & Pericardiccavity & M & Carrilafquen Chica & 3.8 & 1.0 & MLP-He 7137 \\
\hline Tylodelphys destructor & Brain & M & $\begin{array}{l}\text { Carrilafquen Chica } \\
\text { El Chañar }\end{array}$ & $\begin{array}{l}17.0 \\
40.0\end{array}$ & $\begin{array}{l}1.0 \\
2.0\end{array}$ & MLP-He 7138 \\
\hline Tylodelphys barilochensis & Brain & M & $\begin{array}{l}\text { Morenito } \\
\text { Epuyén } \\
\text { Lezana } \\
\text { Marimenuco }\end{array}$ & $\begin{array}{r}6.3 \\
66.6 \\
22.6 \\
14.3\end{array}$ & $\begin{array}{l}4.0 \\
3.0 \\
4.6 \\
4.0\end{array}$ & \\
\hline Stephanoprora uruguayense & Gills & M & $\begin{array}{l}\text { El Chañar } \\
\text { Marimenuco }\end{array}$ & $\begin{array}{r}100.0 \\
42.9\end{array}$ & $\begin{array}{r}57.4 \\
2.3\end{array}$ & \\
\hline Steganoderma macrophallus & Intestine & A & $\begin{array}{l}\text { El Chañar } \\
\text { Musters }\end{array}$ & $\begin{array}{l}40.0 \\
30.0\end{array}$ & $\begin{array}{r}2.0 \\
224.0\end{array}$ & MLP-He 7139 \\
\hline $\begin{array}{l}\text { Steganoderma szidati } \\
\text { Cangatiella macdonaghi }\end{array}$ & $\begin{array}{l}\text { Intestine } \\
\text { Intestine }\end{array}$ & $\begin{array}{l}\text { A } \\
\text { A }\end{array}$ & $\begin{array}{l}\text { Moreno } \\
\text { El Chañar } \\
\text { Marimenuco } \\
\text { Morenito } \\
\text { Moreno } \\
\text { Musters }\end{array}$ & $\begin{array}{r}5.9 \\
80.0 \\
57.1 \\
43.8 \\
64.7 \\
30.0\end{array}$ & $\begin{array}{r}40.0 \\
10.8 \\
4.5 \\
20.3 \\
27.7 \\
9.6\end{array}$ & MLP-He 7140 \\
\hline Contracaecum sp. & Intestinewall & L3 & $\begin{array}{l}\text { El Chañar } \\
\text { Carrilafquen Chica } \\
\text { Morenito } \\
\text { Moreno } \\
\text { Musters } \\
\text { Caleufu }\end{array}$ & $\begin{array}{r}20.0 \\
3.8 \\
6.3 \\
23.5 \\
40.0 \\
33.3\end{array}$ & $\begin{array}{l}2.0 \\
1.0 \\
1.0 \\
1.3 \\
2.0 \\
1.0\end{array}$ & \\
\hline Hysterothylacium patagonense & Intestine & L4 & $\begin{array}{l}\text { Morenito } \\
\text { Moreno } \\
\text { Epuyen }\end{array}$ & $\begin{array}{r}6.3 \\
23.5 \\
33.3\end{array}$ & $\begin{array}{l}3.0 \\
5.8 \\
1.0\end{array}$ & \\
\hline Camallanus corderoi & Intestine & A & $\begin{array}{l}\text { Marimenuco } \\
\text { Morenito } \\
\text { Moreno } \\
\text { Lezana } \\
\text { Musters }\end{array}$ & $\begin{array}{r}42.9 \\
31.3 \\
47.0 \\
3.2 \\
10.0\end{array}$ & $\begin{array}{r}1.3 \\
18.8 \\
12.1 \\
1.0 \\
3.0\end{array}$ & \\
\hline Acanthocephalus tumescens & Intestine & A & $\begin{array}{l}\text { Carrilafquen Chica } \\
\text { Morenito } \\
\text { Rivadavia }\end{array}$ & $\begin{array}{r}14.3 \\
6.3 \\
11.1\end{array}$ & $\begin{array}{l}3.7 \\
2.0 \\
3.7\end{array}$ & \\
\hline Pomphorhynchus patagonicus & Intestine & A & $\begin{array}{l}\text { Lezana } \\
\text { Musters }\end{array}$ & $\begin{array}{r}3.2 \\
90.0\end{array}$ & $\begin{array}{r}1.0 \\
12.8\end{array}$ & \\
\hline Diplodon chilensis & Gills,fins & G & $\begin{array}{l}\text { Carrilafquen } \\
\text { Morenito } \\
\text { Moreno } \\
\text { Epuyen } \\
\text { Rivadavia }\end{array}$ & $\begin{array}{r}28.6 \\
12.5 \\
58.8 \\
100.0 \\
22.2\end{array}$ & $\begin{array}{r}2.8 \\
28.5 \\
35.9 \\
13.6 \\
2.8\end{array}$ & \\
\hline Ergasilus sieboldi & Gills & A & $\begin{array}{l}\text { Marimenuco } \\
\text { El Chañar } \\
\text { Piedra del Águila } \\
\text { Morenito } \\
\text { Moreno } \\
\text { Musters }\end{array}$ & $\begin{array}{r}42.9 \\
40.0 \\
100.0 \\
56.3 \\
88.2 \\
100.0\end{array}$ & $\begin{array}{r}2.3 \\
3.0 \\
2.0 \\
6.0 \\
19.7 \\
46.0\end{array}$ & \\
\hline
\end{tabular}

species since they have an intermediate length to width ratio of the trunk (P. truncatus 3.3 and P. ostraciontis 4.3) (Alexander, 1983).

For cultured $O$. bonariensis, the records herein correspond to the first reports of any parasites. The species richness of silversides collected from floating cages of Lacombe and Chascomús Pampean Lakes, were similar to those collected from wild silversides (Drago, 2012). Although richness was similar between cultured and wild specimens of Lacombe Pampean Lake the composition of the parasite community was different, 
for example T. cardiophilus and Argulus sp. were found only in cultured fish, and Hysterothylacium sp. and Wolffhuggelia matercula only in wild fish (Drago, 2012). This difference can be attributed to the life cycle of the parasites, meanwhile $T$. cardiophilus and Argulus sp. are transmitted by motile larvae (cercariae and juveniles), Hysterothylacium sp. and W. matercula require the consumption of an infected crustacean which are not available for cultured fishes. Silversides cultured in cages, which are located in the Pampean Lakes, acquired parasites from the environment, being of interest to human health Contracaecum sp., which is zoonotic, and for fish health Gyrodactylus sp. and Argulus sp., which could be pathogenic for fish if intensities of infection are increased (Woo, 1995).

Both freshwater silversides species were parasitized by the diplostomids A. mordax and T. cardiophilus, and were recorded in 6 new localities. Besides, Tylodelphys sp., T. destructor, T. barilochensis and Diplostomum sp. were recorded for $O$. hatcheri in 8 new localities. Both freshwater silversides species were parasitized by the heterophyids Ascocotyle sp. and Phagicola sp. constituting 4 new localities, and by the cestodes $C$. macdonaghi representing 7 new localities. Finally, the anisakid larvae Contracaecum sp., were found in $O$. bonariensis and $O$. hatcheri, while Hysterothylacium sp. was found only in $O$. hatcheri; these findings constitute 12 new localities. The following parasites: S. uruguayense (2 records), S. macrophallus (2), S. szidati (1), C. corderoi (5), A. tumescens (3), P. patagonicus (2), and $D$. chilensis (5) were recovered in new localities for $O$. hatcheri; and Gyrodactylus sp. (1) and Argulus sp. (1) represent new localities for $O$. bonariensis. The copepod E. sieboldi was first reported in Patagonia for Percichthys trucha (Cuvier \& Valenciennes) (Szidat, 1956). Additionally larval stages and male specimens of $E$. sieboldi were reported from an Andean Patagonian lake (Modenutti \& Balseiro, 1989). According to Szidat (1956), the Patagonian specimens showed scarce differences with specimens from Europe. Our specimens showed no differences with those collected from P. trucha from Pellegrini Lake and Limay River (Szidat, 1956). As the identity is dubious, we prefer to be conservative and assigned them to E. sieboldi, but molecular studies are needed to confirm the identity of the specimens.

The specimens of $O$. nigricans collected in this study showed a similar richness value (12 species) than those collected in Nuevo and San José gulfs (13 species in both gulfs). Although differences in the composition of parasite communities were observed, both populations share $P$. bartolii, Lecisthaster sp., Cosmocephalus sp., Hypoechinorhynchus sp., and Corynosoma sp., and differ in the presence of Diplostomum sp., Hysterothylacium sp., and C. rogercresseyi found in this study, and Prosorhynchoides sp., Huffmanela moraveci Carballo and Navone, 2007, Anisakis sp., Pseudoterranova sp., and Bomolochus globiceps (Vervoort and Ramírez, 1968) which were found only in the North Patagonian gulfs (Carballo, Navone, et al., 2011). These differences could be attributed to the fact that Nuevo and San José gulfs are in the ecotone between the Argentine and Patagonian ichthyogeographical provinces, while our samples were collected in Tierra del Fuego, in the southernmost part of Patagonian province. Although $O$. bonariensis and
$O$. hatcheri were collected from 2 different ichthyogeographical provinces, Paranoplatensean Province and Patagonian Province, respectively; both share the metacercariae of A. mordax and $T$. cardiophilus and the cestode $C$. macdonaghi. The species of Odontesthes are mainly intermediate hosts for larval stages of Digenea and Nematoda, indicating that silversides in freshwater and marine environments are predominantly prey in the food chains.

\section{Acknowledgements}

To C. Luizon, G. Somoza, L. Miranda, and D. Collauti for their help in the collection of $O$. nigricans and $O$. bonariensis. We are grateful to Nahuel Huapi National Park authorities for sampling permissions. Financial support was provided by UNCo Grant (B-187), PIP 112-200801-01738 CONICET; and PICT BICENTENARIO N ${ }^{\circ} 1293$ Agencia de Promoción Científica y Técnica.

\section{References}

Alexander, P. D. (1983). Peniculus haemuloni, a new species of copepod (Siphonostomatoida: Pennellidae) parasitic on Haemulon steindachneri from Ubatuba, Brazil. Bulletin of the British Museum (Natural History) Zoology, 45, 381-385

Carballo, M. C. (2008). Rol de los pejerreyes Odontesthes smitti y O. nigricans (Pisces: Atherinopsidae) como hospedadores de helmintos en los golfos Norpatagónicos, Chubut, Argentina. Ph.D. Dissertation. Argentina: Facultad de Ciencias Naturales y Museo, Universidad Nacional de La Plata.

Carballo, M. C., Cremonte, F., Navone, G. T., \& Timi, J. T. (2012). Similarity in parasite community structure may be used to trace latitudinal migrations of Odontesthes smitti along Argentinean coasts. Journal of Fish Biology, 80, 15-28.

Carballo, M. C., Laurenti, S., \& Cremonte, F. (2011). A new species of monorchiid digenean from marine fishes in the Southwestern Atlantic Ocean off Patagonia. Systematic Parasitology, 78, 233-240.

Carballo, M. C., Navone, G. T., \& Cremonte, F. (2011). Parasites of the silversides Odontesthes smitti and Odontesthes nigricans (Pisces: Atherinopsidae) from Argentinean Patagonia. Comparative Parasitology, 78, 95-103.

Colautti, D. C., García, J. R., Balboni, L., \& Baigún, C. R. M. (2010). Extensive cage culture of pejerrey (Odontesthes bonariensis) in a shallow pampean lake in Argentina. Aquaculture Research, 41, 376-384.

Daniel, V. I., Timi, J. T., \& Sardella, N. H. (2002). Cucullanus marplatensis sp. nov. (Nematoda, Cucullanidae) parasitizing Odontesthes argentinensis (Valenciennes, 1835) (Pisces, Atherinidae) from Argentinean waters. Acta Parasitologica, 47, 41-46.

Drago, F. B. (2012). Community structure of metazoan parasites of silversides, Odontesthes bonariensis (Pisces, Atherinopsidae) from Argentina. Iheringia, Serie Zoologica, 102, 26-32.

Dyer, B. (2000). Systematic review of the silverside fishes of Chile (Teleostei, Atheriniformes). Estudios Oceanológicos, 19, 99-127.

Dyer, B. (2006). Systematic revision of the South American silversides (Teleostei, Atheriniformes). Biocell, 30, 69-88.

González-Acuña, D., Cerda, F., López, J., Ortega, R., Mathieu, C., \& Kinsella, M. (2009). Checklist of the helminths of the kelp gull, Larus dominicanus (Aves: Laridae) with new records from Chile. Zootaxa, 2297, 27-43.

Grosman, F. (2001). Fundamentos biológicos, económicos y sociales para una correcta gestión del recurso pejerrey. Buenos Aires: Ed. Astyanax.

Lattuca, M. E., Malanga, G. F., Aguilar-Hurtado, C., Pérez, A. F., Calvo, J., \& Puntarulo, S. (2009). Main features of the oxidative metabolism in gills and liver of Odontesthes nigricans Richardson (Pisces, Atherinopsidae). Comparative Biochemistry and Physiology (B), 154, 406-411. 
Locke, S. A., Al-Nasiri, F. S., Caffara, M., Drago, F., Kalbe, M., Lapierre, A. R. et al. (2015). Diversity, specificity and speciation in larval Diplostomidae (Platyhelminthes: Digenea) in the eyes of freshwater fish, as revealed by DNA barcodes. International Journal of Parasitology, 45, 841-855.

Mancini, M., Rodríguez, C., Prosperi, C., Salinas, V., \& Bucco, C. (2006). Main diseases of pejerrey (Odontesthes bonariensis) in central Argentina. Revista Pesquisa Veterinária Brasileira, 26, 205-210.

Mancini, M., Bucco, C., Salinas, V., Larriestra, A., Tanzola, D., \& Guagliardo, S. (2008). Seasonal variation of parasitism in pejerre y Odontesthes bonariensis (Atheriniformes, Atherinopsidae) from La Viña Reservoir (Córdoba, Argentina). Revista Brasileira de Parasitologia Veterinária, 17, 22-38.

Modenutti, B. E., \& Balseiro, E. G. (1989). Presencia de Ergasilus sieboldi en el plancton de un lago Andino Argentino. Anales del Museo de Historia Natural de Valparaíso, 20, 29-30.

Niewiadomska, K. (2002). Family diplostomidae. In D. Gibson, A. Jones, \& R. A. Bray (Eds.), Keys to the Trematoda (Vol. 1) (pp. 167-196). London: CABI

Niewiadomska, K., Zdzitowiecki, K., \& Ostrowski-de Núñez, M. (1989). Redescription of Diplostomum minutum Szidat, 1964 (Digenea, Diplostomidae). Acta Parasitologica Polonica, 34, 267-271.

Ortubay, S., Semenas, L. G., Úbeda, C. A., Quaggiotto, A., \& Viozzi, G. (1994) Catálogo de peces dulceacuícolas de la Patagonia Argentina y sus parásitos metazoos. Bariloche: Dirección de Pesca de la provincia de Río Negro.

Ruiz, A. E. (2007). Biología del pejerrey patagónico en el Embalse Florentino Ameghino, Chubut, Argentina. Córdoba: Universitas.
Stuardo, J., \& Fagetti, E. (1961). Copépodos parásitos chilenos. I. Una lista de las especies conocidas y descripción de tres especies nuevas. Revista Chilena de Historia Natural, 55, 55-82.

Suriano, D. M., \& Sutton, C. A. (1981). Contribución al conocimiento de la fauna parasitológica argentina VII. Digéneos de peces de la plataforma del Mar Argentino. Revista del Museo de La Plata (Nueva Serie), 124, 261-271.

Szidat, L. (1956). Über die Parasitenfauna von Percichthys trucha (Cuv. \& Val.) Girard der patagonischen Gewässer und die Beziehungen des Wirtsfisches und seiner Parasiten zur paläarktischen Region. Archiv für Hydrobiologie, $51,542-577$

Tanzola, R. D., Semenas, L., \& Viozzi, G. (2009). Manejo y estado actual del conocimiento de los parásitos de peces cultivados en Argentina. In M. Tavares-Dias (Ed.), Manejo e Sanidade de Peixes em Cultivo (pp. 438-468). Amapá: Embrapa.

Tombari, A., \& Volpedo, A. (2008). Modificaciones en la distribución original de especies por impacto antrópico: el caso de Odontesthes bonariensis (Pisces: Atherinopsidae). In A. Volpedo, \& L. Fernández Reyes (Eds.), Efecto de los cambios globales sobre la biodiversidad (pp. 155-165). Madrid: Programa Iberoamericano de Ciencias y Tecnología para el desarrollo.

Woo, P. T. K. (1995). Fish diseases and disorders. Vol. I. Protozoan and Metazoan infections. Cambridge: CAB International Press.

Zdzitowiecki, K. (1992). Antarctic representatives of the genus Lecithaster Lühe, 1901 (Digenea, Hemiuridae), with the description of a new species. Acta Parasitologica, 37, 57-63. 